\title{
Leadership in Nursing: Analysis of the Process of Choosing The Heads
}

\author{
Gisela Maria Schebella Souto de Moura' \\ Ana Maria Müller de Magalhaes² \\ Clarice Maria Dall'agnol ${ }^{3}$ \\ Beatriz Cavalcanti Juchem ${ }^{4}$ \\ Daniela dos Santos Marona ${ }^{5}$
}

The process of choosing heads can be strategic to achieve desired results in nursing care. This study presents an exploratory and descriptive research that aims to analyze the process of choosing heads for the ward, in the nursing area of a teaching hospital in Porto Alegre. Data was collected from registered nurses, technicians and nursing auxiliaries through a semi-structured interview technique and free choice of words. Three theme categories emerged from content analysis: process of choosing heads, managerial competences of the head-to-be and team articulation. Leadership was the word most frequently associated with the process of choosing heads. The consultation process for the choice of the leader also contributes to the success of the manager, as it makes the team members feel coresponsible for the results achieved and legitimizes the head-to-be in their group.

Descriptors: Leadership; Health Management; Nursing, Team; Choice Behavior.

\footnotetext{
${ }_{1}^{1}$ Ph.D. in Administration, Professor, Escola de Enfermagem, Universidade Federal do Rio Grande do Sul, RS, Brazil. Center for studies on Nursing Management, Escola de Enfermagem, Universidade Federal do Rio Grande do Sul, RS, Brazil. E-mail: giselasm@terra.com.br.

2 RN, Doctoral Student and Professor, Escola de Enfermagem, Universidade Federal do Rio Grande do Sul, RS, Brazil. E-mail: amagalhaes@hcpa.ufrgs.br.

${ }_{3}^{3}$ Ph.D. in Nursing, Professor, Escola de Enfermagem, Universidade Federal do Rio Grande do Sul, RS, Brazil. Center for studies on Nursing Management, Escola de Enfermagem, Universidade Federal do Rio Grande do Sul, RS, Brasil. E-mail: clarice@adufrgs.ufrgs.br.

${ }^{4}$ RN, Hospital de Clínicas de Porto Alegre, RS, Brazil. Doctoral Student, Escola de Enfermagem, Universidade Federal do Rio Grande do Sul, RS, Brazil. Center for studies on Nursing Management, Escola de Enfermagem, Universidade Federal do Rio Grande do Sul, RS, Brazil. E-mail: bjuchem@hcpa.ufrgs.br.

${ }^{5}$ RN, Hospital de Clínicas de Porto Alegre, RS, Brazil. Master's Student, Escola de Enfermagem, Universidade Federal do Rio Grande do Sul, RS, Brazil. E-mail: dmarona@hcpa.ufrgs.br.
}

Corresponding Author:

Gisela Maria Schebella Souto de Moura Universidade Federal do Rio Grande do Sul. Escola de Enfermagem.

Departamento de Assistência e Orientação Profissional

Rua São Manoel, 963

Bairro Bom Fim

CEP: 90620-110 Porto Alegre, RS, Brasil

E-mail: gmoura@hcpa.ufrgs.br 


\section{Liderança em enfermagem: análise do processo de escolha das chefias}

O processo de escolha de dirigentes reveste-se de importância estratégica para o alcance dos resultados desejados do cuidado de enfermagem. Este estudo apresenta pesquisa exploratória, descritiva, com o objetivo de analisar o processo de escolha de chefias de unidade, na área de enfermagem de um hospital de ensino, tendo-se coletado dados com enfermeiros, técnicos e auxiliares de enfermagem, mediante entrevista semiestruturada e evocação livre de palavras. Da análise de conteúdo, emergiram três categorias temáticas: processo de escolha de chefias, competências gerenciais do futuro chefe e articulação da equipe. Liderança compreendeu a palavra mais frequentemente associada ao processo de escolha de chefia. 0 processo consultivo para a escolha dos chefes contribui para o sucesso da gestão, pois corresponsabiliza os membros da equipe pelos resultados alcançados e legitima o futuro chefe em seu grupo.

Descritores: Liderança; Gestão em Saúde; Equipe de Enfermagem; Comportamento de Escolha.

\section{Liderazgo en enfermería: análisis del proceso de elección de jefes}

El proceso de elección de dirigentes se reviste de importancia estratégica para el alcance de los resultados deseados en el cuidado de enfermería. Este estudio presenta una investigación exploratoria descriptiva, con el objetivo de analizar el proceso de elección de jefes de unidad, en el área de enfermería de un hospital de enseñanza, habiendo recolectado datos con enfermeros, técnicos y auxiliares de enfermería, mediante entrevista semiestructurada y evocación libre de palabras. Del análisis de contenido, emergieron tres categorías temáticas: 1) proceso de elección de jefes, 2) competencias administrativas del futuro jefe $y, 3$ ) articulación del equipo. La palabra liderazgo fue la más frecuentemente asociada al proceso de elección de jefes. El proceso de consulta para la elección de jefes contribuye para el éxito de la administración, ya que responsabiliza a los miembros del equipo por los resultados alcanzados y otorga legitimidad al futuro jefe del grupo.

Descriptores: Liderazgo; Gestión en Salud; Equipo de Enfermería; Comportamiento de Elección.

\section{Introduction}

Care continuity is one of the characteristics of hospital nursing work, where professional alternate in sequential work shifts so as to guarantee continuous 24hour care delivery to users. In this context, nursing care production results from teamwork and its dynamics goes beyond the mere addition of individual efforts. To achieve qualified care results, an equally compatible leadership standard in teamwork is fundamental. This, in turn, is driven and enhanced when a strategic and integrative coordination exists, capable of articulating collective work with a view to achieving common objectives.
In this sense, unequivocal leadership skills are presupposed, which should permeated the role of head, although not all heads are leaders ${ }^{(1)}$. The term head or manager usually remits to the occupation of a function, although the function alone does not make someone a leader. Behaviors and attitudes reveal if a person actually occupies a leadership position ${ }^{(1)}$. Nevertheless, in organizations, expecting every head to be a leader turns into a gold standard.

Besides, in the current stage of work relations, special importance has been granted to leading and 
pro-active teams, stimulated by more collegiate and participatory organizational arrangements that democratize management ${ }^{(1-3)}$. This condition strengthens the need for a careful look at the processes leading to head function in the nursing area. It is considered that, in a way, the (re)production of teams' imaginary on such a relevant issue affects the nurses' profile and respective preparation to occupy strategic formal functions in the hospital structure. In some contexts(4-5), the preparation of nursing staff has even been discussed, in response to the planning of nurses' succession in administrative functions, with visibility and influence in the upward, downward and horizontal flows of organizational life.

In these processes, the double representation role of nurses in head/management functions also needs to be taken into account: on the one hand, they deal with the needs and expectations of the work group they coordinate: on the other, they are faced with needs and expectations demanded by the institution itself, in favor of organizational objectives. In this sense, the challenge of managing health service units entails repercussions among these frontline workers who, amidst daily challenges, start to confront the leadership nurses exercise $^{(6)}$.

In view of these considerations and the relevance of teaching hospitals as models for health practices and knowledge construction, this study aims to contribute to improve management processes, which can reflect in better outcomes for patients and professionals.

The general aim was to analyze the process of choosing unit heads in the nursing area of a teaching hospital. The specific aims were to: identify criteria different team segments use (nurses, nursing technicians and auxiliaries) to choose candidates; to describe strategies used to articulate the election; and, finally, get to know expectations about the future head.

In the hospital that served as the study scenario, the selection process of unit heads occurs through a participatory proposal, in which nurses, nursing technicians and auxiliaries participate in the choice of their head, in their work sector, by vote. This occurs from the perspective of a consultation process and, as such, is not vested with exclusive autonomy, as the results of these consultations compose name lists, generally triple, for appreciation by the central administration (CA). One of the prerogatives of the $\mathrm{CA}$ in the final decision refers to possible ties between candidates, on the occasion of the consultation process, besides other specific situations. Despite this configuration, across successive management mandates, the consultation vote has been quite defining in the choice of the nurses for these head functions.

It should be highlighted that the participatory process to choose managers is not an alternative that plays itself out in the solution of organizational problems. Participation presupposes maturity, preparation and commitment of all stakeholders to achieve positive results. The "voters" need to be aware of the importance of their "vote" and ability to distinguish the candidates" potentials and weaknesses regarding leadership attributes, with a view to a satisfactory exercise of the head function.

\section{Method}

Reflection on the theme led to an exploratory and descriptive research design. Exploratory studies allow researchers to evaluate situations related to human behaviors, identifying relevant variables, setting priorities and suggesting research hypotheses. These studies rarely represent an end in themselves, unveiling possibilities for further research on the theme ${ }^{(7-8)}$. The goal of descriptive research is to observe, describe and document the aspects of a situation ${ }^{(9)}$.

\section{Place of study and subjects}

The study was carried out at a teaching hospital that is part of the Ministry of Education's hospital network. At the time of study, the hospital offered 749 beds and approximately 4,416 employees, 1,841 in the nursing area, 441 of whom were nurses. Among the 284 faculty of Universidade Federal do Rio Grande do Sul directly involved in the conduction of processes and activities that move the organizational structure, there were 28 nursing professors.

The subjects totaled 62 nursing professionals, including nurses, technicians and auxiliaries in 34 sectors, commonly called units.

To compose the sample, a draft was held, adopting participation as a "voter" in the last consultation process to choose unit heads as the inclusion criterion. Nurses who had been occupying this function at the time of data collection and employees on extended leaves or vacation were excluded.

\section{Data collection and analysis procedures}

Data were collected between June and September 2009, during the interviewees' work journey, at a unit room, guaranteeing the privacy of the interview. Interviews took between 15 and 20 minutes and were held by the project team. 
The audiotaped procedure started with the free association technique, asking the subjects to freely and rapidly choose words related to the inducing question: "what three words come to your mind when you hear the expression selection process of unit heads?" Next, an interview was held, based on a script with semistructured questions. Participants were asked to freely express their opinion and report their experience on the study theme, highlighting criteria used to choose the unit head, strategies employed in this process and expectations regarding the future head.

After the literal transcription of information, thematic category analysis was carried out(10), adding information from the free association of words and the semistructured interview questions. At first, the words the subject chose were simply quantified, according to the order of importance attributed. Then, points of convergence and reinforcement were verified, as well as complementariness explicit in the interlocution of these contents with the testimonies that resulted from the reports, in the interviews. The results were grouped in three thematic categories.

\section{Ethical precautions}

Approval for the research project was obtained from the Institutional Review Board of the study institution, under number 07-275.

The subjects agreed with the audiotaping of the interviews by signing the Informed Consent Term (ICT). To maintain information anonymity, the subjects' statements were number coded, following the order of the interviews.

\section{Results and discussion}

In the free choice technique, leadership was the word the interviewees most mentioned: it appeared 22 times as a word related to the expression "selection process of unit heads", among 185 manifestations. When analyzed per position - first, second and third -, it was also the most mentioned word.

The appearance frequency of a word suggests an intense relation of meanings between the terms head and leadership. On the one hand, this fact can indicate conceptual confusion, deriving from common sense, between both terms, as mentioned in the introduction to this paper; on the other, it can appoint leadership as a necessary competence for future heads.

With regard to the other words, one group was mentioned between two and five times per position.
Some focused on the selection process of the heads: to give an example, democratic, choice, group, election, change; while others focused on the future heads' management competencies: for example competency, knowledge, responsibility, seriousness, confidence, impartiality, understanding, humanization. The remaining words mentioned were expressed only once, constituting quite a heterogeneous universe, which did not permit constituting any category.

Content analysis of the open questions supported the classification of the two groups mentioned above and added a third category, i.e. the form the team articulates for the head selection process.

Next, the three categories are described, constructed based on the analysis of information that resulted from the semistructured interviews. Literal transcription of the interviews was used to illustrate the categories.

\section{The process of choosing heads: a dynamic process}

When referring to the choice of nursing heads, the nursing professionals emphasize the dynamic, democratic and participatory aspect of this process. Some perceive the construction of this space as a distinguishing point of nursing in comparison with other hospital areas, where the choice of heads does not follow a consultation model, and where there is no discussion or participation in the definition of names to occupy management functions that will lead teamwork. The following excerpts illustrate this idea:

At the hospital, it is the only service, which is nursing, that does this choice process and I think that's very important, because it's democratic, let's say [...]. You can choose (10). So the consultation process is one of the ways for us to express, through a vote, our dissatisfaction or satisfaction with that person or the new person who will assume a head function (15).

Although the democratic and participatory aspect is highlighted, the way some units are led is also criticized, when the heads themselves, the nurses and, in some cases, colleagues express feelings of fear and oppression when defense of one candidate's name is articulated. One nursing auxiliary expressed this in the following excerpt:

At some units, the previous head exerted pressure, intimidated people to vote for the person she wanted [...] We didn't have that problem, but we know that people were pressured at some units (23).

The idea of team and leadership as a groupconstructed phenomenon also permeates the respondents' discourse. In this sense, the following statements indicate the importance of participating in 
the choice of one's own head-of-staff, and indicate that this process mobilizes group members to define their leaderships:

[...] you can choose the people you identify as the best and help in this process. Because I think that leadership does not come alone, group work is needed (10). [...] marvelous. Because they give you the opportunity to choose, right. It is not something imposed (3).

Experiences with the process of choosing heads, by vote or consultation, are pictured as important for group growth, but experiences are also appointed in which the chosen heads did not continue occupying their function, demonstrating a weakness in the process or leaderships' lack of preparation to assume teamwork coordination functions, and the team's lack of preparation to indicate a leadership capable of assuming the burdens a unit head. This idea is illustrated in the following excerpts:

Because it didn't work any of the other times, people quit. And I came here, the person who won also quit (3). [...] perhaps if more people thought together, for people to be able to vote without fear (17).

When they describe the selection process of heads or define the criteria for this choice, the respondents manifest the importance of maintaining this type of participation by the work team. However, one obstacle that is raised is the lack of leaderships in work groups, due to the fact that, at different times, there was only one candidate to run for head. The presence of only one candidate is described as a factor that contributes to decreased opportunities for debate and discussion, which the study participants see as a way to express team members' anxieties and commit candidates to the joint construction of proposals for the area. The occurrence of situations with two or three candidates was expressed few times, as shown in the following statements:

This is the third election process I participate in. The first process, when I entered the hospital, had more candidates. There were at least three candidates when I worked at the pediatric hospitalization unit. Then, the other two processes were here, and then there was only one single candidate [...] (9). [...] of everything and also because there was not much of another option, among those we saw here as heads, we couldn't see anyone who could be a head and all that among the others (11).

The participatory process is one of the available routes to identify leaderships. It can count on group members' perspicacity to identify people with characteristics that favor the exercise of leadership, for themselves and the team, considering that all individuals can potentially develop leadership, even if they often have not discovered and developed this yet.

\section{Management competencies of future heads}

In the analysis of the criteria adopted to choose the heads, strong emphasis was observed on the technical, administrative and relational skills a leader needs to manage an area. In this respect, the teams acknowledge an intricate relation between leadership and management.

The respondents refer to the importance of a future head mastering knowledge and technical competency in the specific nursing area, demonstrating acknowledged clinical skill, through high-quality nursing care to patients and families. Technical skill presupposes critical reasoning to evaluate clinical conditions and patient needs, besides elaborating nursing diagnoses and interventions that can lead to the best care results. Knowledge on equipment, material and resources is also expected with a view to developing care actions. The following statements illustrate these ideas:

Someone you have already been observing in daily reality. Competence, the person needs to be component. They have to know the unit well, it's not knowing the unit, it's knowing the service that exists at the unit, knowing the importance of the nurse, of other professionals, of the organization, what's a priority (21). [...] her time on the job, her experience at this and other hospitals... that she is always studying, wanting to have a new vision (32).

In line with literature, this finding highlights the importance of the team identifying with the way the nurses act with patients and the work team, in their performance as clinical nurses (bedside nurses). The team identifies leaders based on the passion they demonstrate in patient care, reflected in the high quality of nursing care. Similar behavior favors motivation, enthusiasm and the feeling that leaders are strongly connected with team needs( ${ }^{(3)}$.

Acknowledging that care is the essence of nursing, leadership values should be oriented in this sense ${ }^{(11)}$. Hence, it can be inferred that nurses' acknowledgement with good clinical or care performance is a fundamental factor for the team to accept them as possible leaders or future heads, besides contributing to the recovery of care as the central focus of nursing leadership.

Administrative skill is addressed by the need to master processes, unit structure and material resources needed to develop care actions. The importance of mastering administrative standards and rules is also highlighted, as well as the view of the institutional structure and its determinants in the unit organization. Thus, besides the specific perspective of the unit, 
leaders/heads should develop a broad view of the entire institution and interactions occurring at all levels, affecting the daily reality at their workplace, in accordance with the following statements:

[...] knowledge of hospital structure because, although it is a closed area or a unit like... understanding this structure, this institution (1). It should be a very accessible, flexible person, with a broad view of the entire unit, impartial, willing to maintain what's good and change what wasn't so good (18). [...] thy need to have a general view of everything. They need to have eyes for everything (19).

Administrative skills expected in future heads' management competencies remit to literature studies that indicate the relevance of nurses' developing knowledge and competencies based on management, leadership and power research(12-13).

Relational skills were underlined as an essential characteristic of future leaders, and the interviewees described it as the ability to deal with people, know how to listen, share, work in groups and motivate team members:

[...] a leader has to know how to work with other people, stimulate these people, not just charge them (14). [...] accessible, flexible, with a broad view of the entire unit, impartial, with [...] Who knows how to hear other people's opinion, not simply imposing one's own thoughts (18). The person's humane part as well, because it's no use to be a good leader without that part you need, to be more humane (29).

Nurse leaders' interpersonal dimension and human competence represents motivation and support for teamwork. The leaders' capacity to perceive, attend to and be connected with the work team's needs reinforces the feeling of belonging and nourishes all group members' self-esteem, with a view to achieving excellence in clinical practice. Successful leaders acknowledge each person as a universe of needs, understand that each person reacts differently to stress factors in the work environment and give support to the group, offering feedback, so that each member feels valued(14-15).

Even if knowledge is considered irreplaceable in clinical practice, it cannot do without the interpersonal dimension of relationships, which are constructed based on experiences, inferences, interpretations and creativity of know-how ${ }^{(15)}$. Thus, leaders/heads' relational skills are considered the capacity to integrate technical and administrative knowledge in a concrete practice that allies the rational and human of each situation.

The candidates' responsibility and the trust vested in them are appointed as fundamental elements in criteria to choose heads. Responsibility is acknowledged by the candidates' behavior, attitude and performance as a team member in other positions than that of head, and confidence is described as something constructed throughout the relation and interaction with work team members.

Managers' capacity to establish relations of trust and respect among team members can help each member to perceive that they will be supported at difficult times, that leaders will fight for everyone and will always be present $^{(16)}$.

Based on the appointed factors, a trend can be inferred for teams to support candidates from their own unit, who are already known for their work as team members in different roles, as exemplified in the following statements:

[...] the group will normally choose someone trusted, who works well, who works well for patients as well as for employees [...] contact shows us a lot (4). Knowing the person, trust. Trust in that person's ability (3). [...] I'd vote exactly because I know how she works (20).

Among management competencies in the technical, administrative and relational dimensions, criteria were listed that are considered fundamental to choose a head/ leader, highlighting transparence in the management process, emotional and rational intelligence, leadership and group work skills, participatory management, competence in interpersonal relationships, honesty, aptitude and sense of justice.

\section{Team articulation}

Groups' internal articulation goes through different stages. Some involve mobilization, organization of meetings, debates and elaboration of joint proposals; in others, the process is more centralized on the nurses and informally discussed with team members.

When investigating how the team gets organized to prepare the process of choosing heads, an internal division was evidenced in the groups, identified in expressions like "they" (nurses) and "we-employees" (technicians and auxiliaries). What is remarkable in this process is the manifestation of the difference between different professional nursing categories, characterized by the distancing between nurses and nursing auxiliaries/technicians. This finding was more present in the auxiliaries and technicians' statements, as pictured in the following excerpts:

The names came, as far as I can remember, already indicated by the nurses (6). Because the candidate whom, let's say, the nurses wanted to put forward, the technicians would not accept, so they sought an external head, an external candidate 
[...] agreement between the nurses and the other who used to be the head (11).

The distancing that exists between nurses and nursing auxiliaries/technicians has already been addressed as one of the main bottlenecks in work team relations $^{(17)}$. One of the possible explanations for the origin of this situation can be related to the technical and social division of work, decisively affecting the construction of group relations ${ }^{(18)}$.

Besides the hierarchy of relations, in the respondents' statement, a sense of not belonging to them team is perceived (they/we; they/our group; the nurses/the employees). Mainly nursing auxiliaries and technicians refer to the nurses as distant professionals, and not as employees in the same condition and who are part of the same team and the same institution.

It departs from them, the nurses. They launch their list and we have to choose [...] it's still very closed between supervision and employees. I think it should be more open (2). [...] they held various meetings [...] they talked to us (12). I don't know, that's something they choose. We just analyze the candidates after they are chosen (32). They generally determine the name of the candidates [...] the nurses themselves. We are not involved in that issue. We get involved only afterwards, in the election, in the choice of previously given names (28).

The emergence of divisions and subgroups in the teams partially pictures how difficulties are faced and how internal power relations are woven. In some cases, power is polarized between people, characterizing a hierarchy in the relations that tends to be reproduced in the technical and social division of work: those who think "can do more" and give orders to those who know less and, therefore, "can do less"(19).

On the whole, the statements suggest different practices and management modes between the teams. Thus, against previous statements, others indicate the existence of teams with an underlying more integrative and cooperative space for communication and construction. It is presupposed that, in these cases, the group manages to act operatively, towards collective strengthening. Even if they recognize differences, spaces for dispute and conflicts, they seek strategies for overcoming and continuous learning in the work environment, with a view to improving interpersonal relations, as illustrated in the following comments:

[...] we chose her even before the end of her mandate, because she didn't want to continue. So, it was a very nice process, because we held a campaign for her to stay. Instead of her campaigning, we did it. We convinced her to stay in fact (7). [...] the experience was different because I participated since the start of the process, I was part of the sub-commission, we organized everything (8).

The aspects appointed in the teams' articulation to construct a collective process of choosing heads indicate a vulnerable point area professionals need to discuss, as the groups' internal division does not enhance everyone's efforts to transform realities in nursing contexts.

\section{Final considerations}

The selection process of the heads, when based on the nursing workers' opinions, through vote, is an attempt to put in practice a participatory management model, as verified in the context of this study. This process, however, is permeated by bias and peculiarities inherent in human relations at work, in which different needs have to be made compatible, remitting to the individual, the work team and the organization as a whole. When considering the achievement of these needs, voters and candidates are faced with bilateral expectations and commitments that are interwoven. In this sphere, leadership is the key word, as appointed in this study.

Although complex, the exercise of leadership is inherent in the work organization and influences the teams' articulation. Moreover, it also gains a special meaning in the choice of heads-of-staff, to the extent that, explicit and implicitly, the head is expected to be a leader. The subjects' statements illustrate that this is an important aspect interfering in the election on the occasion of the consultation process.

At first sight, realizing that one needs technical competency, management skills and talent for a good interpersonal relation can discourage professionals who do not find themselves with all of these qualities. It should be acknowledged, however, that these attributes can be developed in daily nursing practice, even in nursing working in clinical care, at the bedside, which underlines the indissociability between management and care.

Clinical practice constitutes an excellent laboratory to also exercise the technology of know-how in the leadership process and, as highlighted in this study, it is exactly during this practice that the work group acknowledges the team's potential leaders.

The fact of granting work groups the opportunity to participate in the choice of heads-of-staff contributes to successful management, to the extent that it makes team members co-responsible for the achieved results. Besides, the strategy contributes to the group's acceptance of the new head. 
Finally, it is considered that nursing work is generated in the articulation of group work, among teams alternating in consecutive patient care shifts and whose results should surpass the sum of individual efforts. Hence, group operativeness needs to be constructed and receive feedback in daily work interactions, expecting the head, as a legitimate leader, to effectively assume the role of articulator and motivator in this context.

\section{Acknowledgments}

The authors acknowledge the valuable collaboration of the nurse Rosana Fraga da Silva and the students Dayanna Machado Lemos, Andréia Peres de Oliveira and Louíse Viecili Hoffmeister, in the data collection.

\section{References}

1. Marquis $\mathrm{BL}$, Huston CJ. Administração e liderança em enfermagem: teoria e prática. 4.ed. Porto Alegre: Artmed; 2005. 477 p.

2. Bernardes A, Cecilio LCO, Nakao J, Évora YDM. Os ruídos encontrados na construção de um modelo democrático e participativo de gestão hospitalar. Ciênc Saúde Colet. 2007;12(4): 861-70.

3. Stanley D. Congruent leadership: values in action. J Nurs Manage. 2008; 16(5):519-24.

4. Ponti MAD. Transition from leadership development to succession management. Nurs Admin Q. 2009; 33(2):125-41.

5. Raholm MB. Evidence and leadership. Nurs Admin Q. 2009; 33(2):168-73.

6. Santos I, Oliveira SRM, Castro CB. Gerência do processo de trabalho em enfermagem: liderança da enfermeira em unidades hospitalares. Texto Contexto Enferm. 2006;15(3):393-400.

7. Sampieri RH, Collado CF, Lucio PB. Metodologia de la investigación. México: McGrawHill; 1991. 128 p.

8. Erdmann RH. Organização de sistemas de produção. Florianópolis (SC): Insular; 1998.

9. Polit DF, Beck CT, Hungler BP. Fundamentos de pesquisa em enfermagem: métodos, avaliação e utilização. 5.ed. Porto Alegre: Artmed; 2004. 487 p.

10. Bardin L. Análise de conteúdo. Lisboa: Edições 70; 1977.
11. Sousa LB, Barroso MGT. Reflexão sobre o cuidado como essência da liderança em enfermagem. Esc Anna Nery Rev Enferm. 2009;13(1):181-7.

12. Garcia IG, Santa-Barbara, ES. Relationship between nurses' leadership styles and power bases. Rev. Latino-Am. Enfermagem. 2009;17(3):295-301.

13. Lourenco MR, Shinyashiki GT, Trevizan MA. Management and leadership: analysis of nurse manager's knowledge. Rev. LatinoAm. Enfermagem. 2005; 13(4):469-73.

14. Frankel A. What leadership styles should senior nurses develop? Nurs Times. 2008 [acesso: 17 ago 2009]; 104(35): 23-4. Disponível em: http://www.nursingtimes.net/1811643. htm

15. Strapasson MR, Medeiros CRG. Liderança transformacional na enfermagem. Rev Bras Enferm. 2009;62(2):228-33.

16. Dols J, Landrum $P$, Wieck KL. Leading and managing an intergenerational workforce. Creative Nur. 2010;16(2):68-74.

17. Cardoso ASF. Análise de um processo grupal de uma equipe de enfermagem [dissertação de mestrado]. Porto Alegre (RS): Escola de Enfermagem/UFRGS; 2009. 99 p.

18. Dall'Agnol CM, Ciampone MHT. Avaliação de desempenho: diálogos e representações de um grupo na enfermagem. Rev Bras Enferm. 2002;55(4):363-9.

19. Fortuna CM, Mishima SM, Matumoto S, Pereira MJB. O trabalho de equipe no programa de saúde da família: reflexões a partir de conceitos do processo grupal e de grupos operativos. Rev. Latino-Am. Enfermagem. 2005; 13(2):262-8. 